\title{
Lectotypification and recollection of Bulbophyllum crabro in Meghalaya after 125 years
}

\author{
Shankar U. \\ Department of Botany, North-Eastern Hill University, Shillong, Meghalaya - 793 022, India \\ E-mail: arshuma@yahoo.com
}

\begin{abstract}
A rare epiphytic sympodial orchid, Bulbophyllum crabro (C.S.P.Parish \& Rchb.f.) J.J.Verm., Schuit. \& de Vogel was recorded in 2016 from Meghalaya for the first time since 1891 (as Monomeria barbata Lindl.). The growth of this orchid was studied over three seasons between 2016 and 2020 in the campus of the North-Eastern Hill University, Shillong. The results expand the imperfect taxonomic description and document the intriguing flower structure with photographs. An English name, 'the bull's head flower', is proposed for this taxon, based on the appearance of the labellum or lip. The names Monomeria barbata Lindl. and Monomeria crabro C.S.P.Parish \& Rchb.f. are lectotypified here.
\end{abstract}

Keywords: Bull's head flower, Epicranthes barbata, Monomeria barbata, Monomeria crabro, Northeast India, Orchidaceae.

\section{Introduction}

Lindley (1830) described the genus Monomeria Lindl. (Orchidaceae) based on the species Monomeria barbata Lindl. The genus name referred to the presence of mono=one and mer=part, probably referring to 'one anther'. Lindley (1830) distinguished Monomeria from the similar Bulbophyllum Thouars (1822) based on the absence of the lateral petals. Lindley's position of abortive petals was later dismissed by Rolfe (1910). In 1871, Rev. C.S.P. Parish collected a similar plant from Myanmar and Reichenbach (1874) described it as a new species in Monomeria, M. crabro C.S.P.Parish \& Rchb.f., with a line drawing showing the

Received: 19.10.2020; Revised \& Accepted: 29.09.2021

Published Online: 16.10.2021 presence of lateral petals. The striking similarity of M. barbata to M. crabro, apart from the lateral sepals, led taxonomists (e.g., Bentham, 1881) to wonder whether the two were the same taxa, and Hooker (1890) synonymized M. crabro under M. barbata.

Pantling collected material of $M$. barbata from Sikkim in 1891 and King from Sondai, Nepal, in 1893. Based on these collections, King and Pantling (1898 a,b) updated the description of Monomeria and its only species $M$. barbata along with the first partially coloured drawing. Subsequently, the genus was collected from localities in the Indo-Malayan biogeographical region, with small populations in all localities (Grant, 1895; Kerr, 1911; Seidenfaden, 1986; Averyanov, 1994, 1998; Averyanov et al., 2000; Pearce \& Crib, 2002; Kress et al., 2003; Averyanov \& Averyanova, 2003, 2013; Abdullah, 2007; Chen et al., 2009; Jin \& Zha, 2009; Chen \& Vermeulen, 2009; Xu et al., 2010; Ormerod, 2011; Pridgeon et al., 2014).

King and Pantling (1898a: 152) made a passing reference to a collection of $M$. barbata from 'Khasia hills by Rita', but without mentioning of gathering number or collection date. Unfortunately, Rita's collection is not traceable. Quoting King and Pantling (1898a), Rolfe (1910: 31) mentioned 'Khasia' as habitat and clarified that the petals are present, but reduced to a few minute teeth situated at the foot of the column. There is no voucher of the species from Khasia hills or anywhere in Meghalaya deposited in ASSAM or CAL (Shankar, pers. obs. 2020). Mao et al. (2016) included the species in the checklist of Meghalaya without citing any specimen or literature, but Singh et al. (2019) 
did not mention Meghalaya in its range. Reports of the occurrence of $M$. barbata by various authors (Hajra \& Verma, 1996; Lucksom, 2007; Shankar, 2021) are based on collections from Sikkim. Hence, the present collection represents the rediscovery of this orchid from Khasia hills about 125 years after Rita's collection. This article aims at providing a detailed and updated description and photographs of this taxon. Vermeulen et al. (2014) transferred Monomeria crabro to Bulbophyllum as B. crabro and placed it under the section Monomeria (Lindl.) J.J.Verm., Schuit. \& de Vogel.

\section{Materials and Methods}

The specimen was collected from 'Khasi Hill Sal' type forest (Tripathi \& Shankar, 2014) in Nongkhyllem Wildlife Sanctuary $\left(25^{\circ} 57244.853\right.$ $\mathrm{N}, 91^{\circ} 50212.143 \mathrm{E}, 760 \mathrm{~m}$ ) in the Ri-Bhoi district of Meghalaya in 2016. It was grown in homegarden under protection and observed consistently in the North-Eastern Hill University, Shillong, to build a morphological description. A voucher specimen has been deposited in ASSAM.

\section{Taxonomic Treatment}

Bulbophyllum crabro (C.S.P.Parish \& Rchb.f.) J.J.Verm., Schuit. \& de Vogel, Phytotaxa 166: 106. 2014. Monomeria crabro C.S.P.Parish \& Rchb.f., Trans. Linn. Soc. London 30: 143. pl. 28. 1874. Lectotype (designated here): Trans. Linn. Soc. London 30: 143, pl. 28. 1874.

Epicranthes barbata (Lindl.) Rchb.f., W.G.Walpers, Ann. Bot. Syst. 6: 265. 1861, non Bulbophyllum barbatum Barb.Rodr., 1881. Monomeria barbata Lindl., Gen. Sp. Orchid. Pl. 61. 1830. Lectotype (designated here): NEPAL, Toka, 1821, Wall. Cat. 1978 (K [K000974273 digital image!]: isolecto K [K000974243, K001114839 digital images!]; G [G00434759 digital image!]).

Figs. $1 \& 2$

Rhizome creeping, stout, woody, c. 5-7 $\mathrm{mm}$ in diam., sympodial, rooting profusely from below current years' pseudobulbs, often giving rise to two new rhizome branches from axillary buds at $c .120^{\circ}$ angle in either direction of feeder (older) rhizome (i.e., iterative bifid branching pattern with 'Y'shaped appearance); rhizome segments $c .1 \mathrm{~cm}$ (segments disappear with age), green, splashed with purple spots. Pseudobulbs spaced on rhizome by $c$. 6-8 cm, ovoid, lemon green, c. 3-5 cm in height, 2-4 cm in diam., green, shiny when new, moderately shrivelled after flowering, getting flaccid with age, finally degenerating; leaf single at apex. Petiole c. 6-10 cm long; blade oblong with blunt emarginate apex (mostly symmetrical), c. 16$25 \times 3-4 \mathrm{~cm}$, coriaceous or thickly leathery; both surfaces glabrous, one-nerved; base contracted, decurrent into petiole. Scape slender but stout, as long or slightly longer than leaves, $30-35 \mathrm{~cm}$ in length, arising laterally from base of pseudobulb, generally one scape from each pseudobulb, ascending, dark purple spotted with green, laxly racemose; internodal length $c .1 .5-2.5 \mathrm{~cm}$, horizontal; peduncle $10-16 \mathrm{~cm}$, stout, $2-4 \mathrm{~mm}$ in diam., with 3-5 sheaths of 6-10 $\mathrm{mm}$; floral bracts linear-lanceolate, c. 5-6 mm, persistent, one-fourth or shorter than pedicelled ovary of $c .2 \mathrm{~cm}$. Flower ringent, c. $3 \mathrm{~cm}$, laxly arranged on scape in spiral alternation, spaced at $1.5-2.5 \mathrm{~cm}$, bilaterally symmetrical; nectar present. Sepals 3, persistent, unequal; dorsal sepal larger, longer than lateral sepals, adnate to one-half of the brim of ovary on base of column, erect, concave-curved behind column forming hood, ovate, acuminate, c. $12 \times 5$ $\mathrm{mm}$, veined, exterior umber-brown coloured, interior yellowish; lateral sepals joined on margins of terminal end of foot, arranged parallel to each other at $180^{\circ}$ angle from dorsal sepal as prongs of tuning fork, somewhat oblong, pineapple-yellow, tinged with caramel-brown dots, c. $24 \times 8 \mathrm{~mm}$, veined, adaxially densely hispid, margins recurved, distal edges of lateral sepals connate at sub-apex to each other, yellow without tinge, terminating into an acuminate, drooping apex; lateral sepals sensitive to stimulus, quickly writh if plucked (not just touched). Petals 3, caducous; lateral petals obliquely triangular, minute, c. $3 \times 2.5 \mathrm{~mm}$, margins erose or slightly fimbriate, connate, adnate to other half of brim of ovary at base of column, strongly decurrent 


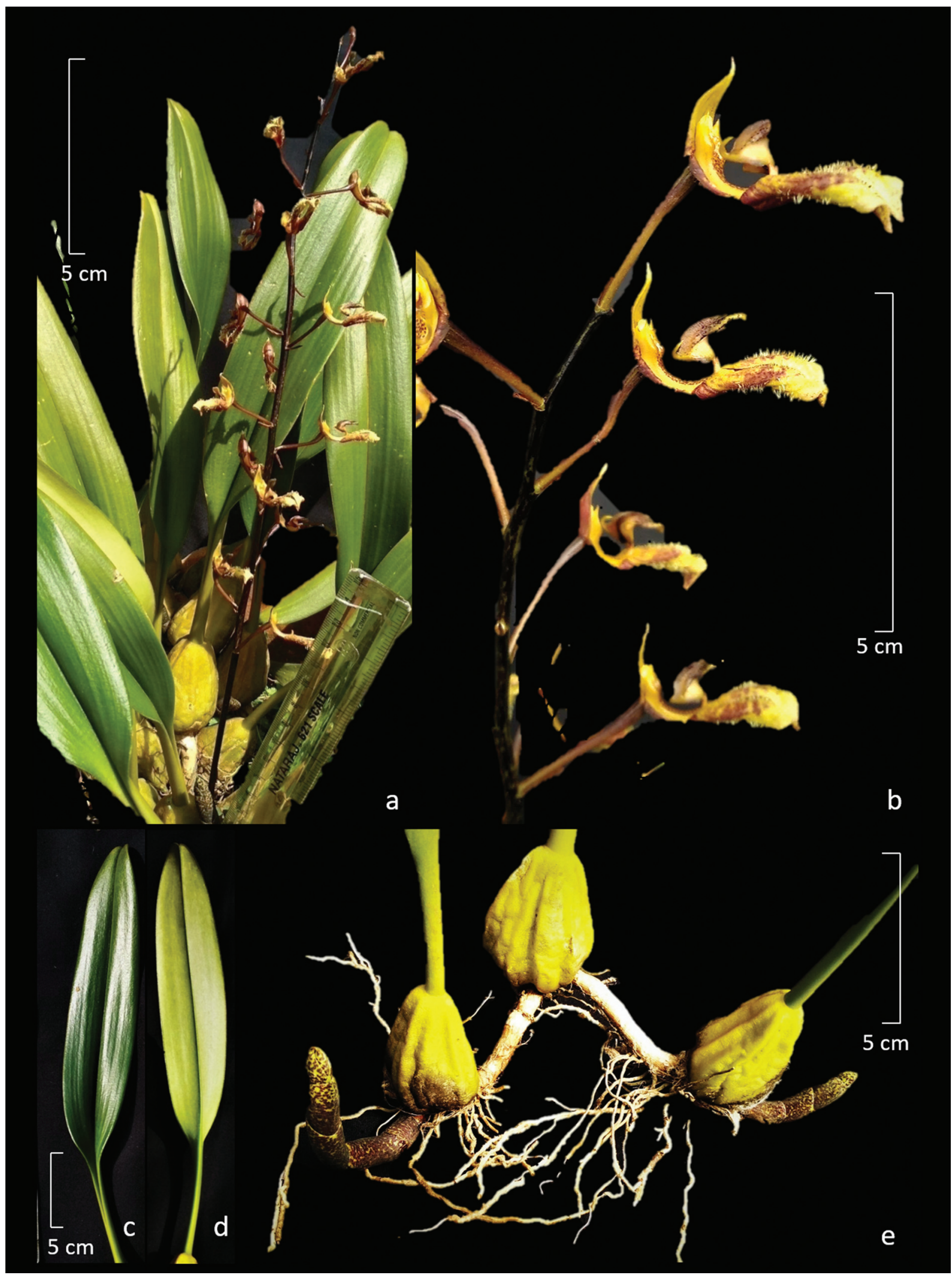

Fig. 1. Bulbophyllum crabro (C.S.P.Parish \& Rchb.f.) J.J.Verm., Schuit. \& de Vogel: a. Habit; b. Scape (inflorescence); c. Adaxial leaf surface; d. Abaxial leaf surface; e. Preceding year's pseudobulb borne on a creeping rhizome (centre) giving rise to two new pseudobulbs at about $120^{\circ}$ exterior angles (left and right) bearing remnants of degraded sheath as well as fibrous roots at the base, and extending purple-spotted greenish rhizomes for future development of pseudobulbs (photos by Uma Shankar). 


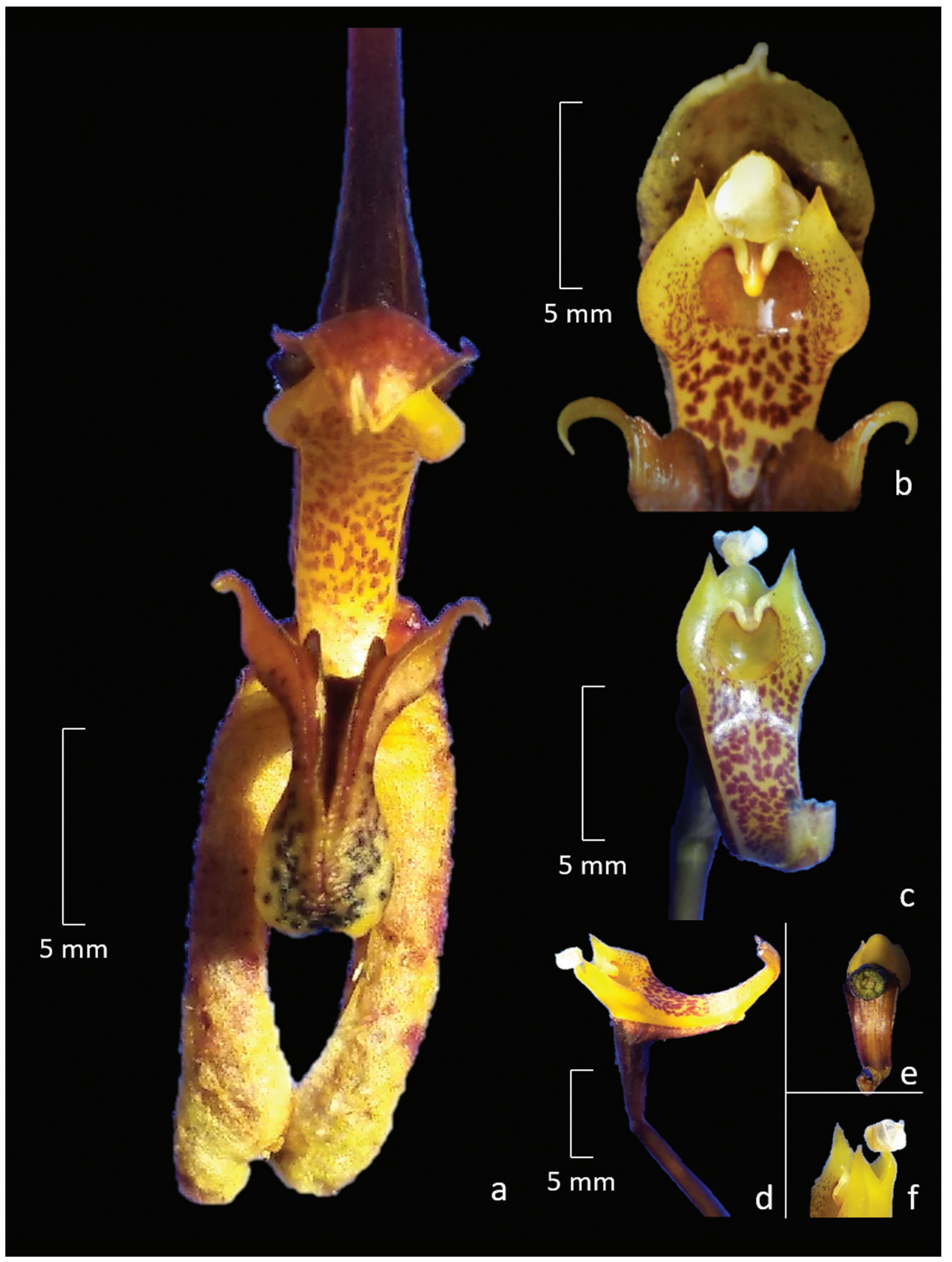

Fig. 2. Flower morphology of Bulbophyllum crabro (C.S.P.Parish \& Rchb.f.) J.J.Verm., Schuit. \& de Vogel: a. Overhead view of a single flower; b. Front view of column, depicting gynandrium protected by the dorsal sepal; c. Full front view of column-and-foot after excising sepals and lip; d. Lateral view of column, showing pedicel-with-ovary and recurved foot; e. Transverse section of ovary showing thick ovary wall housing ovules; f. Close-up of androecium, comprising one fertile anther and two sterile ones called stelidia (photos by Uma Shankar). 
on posterior side of foot, extending to distal end of foot until interposed between joints of lateral sepals on margins of foot, petals glossy purple on decurrent exterior; lip panduriform, 3-lobed, with two basal lobes diverging towards column, one terminal (lateral) lobe deflexed about middle towards distal end; two small, narrowly falcate (horn-like) auricles on basal lobes; terminal lobe (mid-lobe) somewhat larger with apex obtuse, surface of fresh lip lutescens or vitreous, shiny; disk with four pairs of erect, membranous, purple lamellae articulating the shape of lip, three pairs of lamellae visible adaxially, one pair visible only abaxially, two adaxial pairs of lamellae appear converging towards mid-lobe, all four lamellae on each lobe taper, merge gradually to shape hornshaped auricles. Seating of lip hinged on upcurved end of column foot by movable joint allowing restricted flexion (towards anterior), extension (towards posterior) movements; lip imparts appearance of bull's head. Column stout, curved, 16-20 mm including foot, yellow studded with purple-brown spots predominantly on foot region up to stigmatic chamber, bearing dilated wings on both sides around stigmatic chamber, each wing bearing one erect deltoid stelidium, giving rise to hook-shaped arm towards central-top of stigmatic chamber, joined with each other to form ' $U$ '-shaped rostellum aligned over stigma, third projection smaller than stelidia, hindmost representing filament of stamen, bearing one anther; foot, attenuated, upcurved, 10-12 mm. Stamen one, fertile; filament yellow, curved with rounded top bearing single anther; outer wall of anther forming helmet-shaped anther cap housing four white pollinia jointed by common stipe inserted vertically in rostellum, held by deep-yellow ovoid-globose viscid gland or viscidium; pollinia waxy, in two pairs, caudiculate, cohering into sub-globular mass, attached to stipe, caudicle of pollinia brittle. Gynoecium typically jointed as pedicel-with-ovary; stigma fused in gynandrium; stigmatic chamber large, bowl-shaped vertical cavity with interior shiny yellow, viscid, stigma rests on bottom of chamber flanked by two yellow nectary glands, several ovules enclosed within thick ovary wall.
Flowering \& fruiting: Flowering synchronous, November through mid-January, flowers lasting generally up to six weeks before withering during coldest month of the year, i.e., January; fruiting not seen.

Habitat: Grows on tree trunks (this study) or on rocks (lithophyte or rupicolous, Chen \& Vermeulen, 2009) at c. $760 \mathrm{~m}$ altitude. Capable to grow on garden trees and also in shallow planters as ornamental.

Distribution: Northeast India, Bhutan, China, Myanmar, Nepal, Peninsular Malaysia, Thailand, Vietnam (POWO, 2020).

Specimens examined: INDIA, Sikkim, 02.1891, R. Pantling 124(CAL [CAL0000054299, CAL0000054300, CAL0000081609, CAL0000081610]). NEPAL, Sondai, 29.01.1893, G. King, s.n. (CAL[CAL0000081611, CAL0000081612, CAL0000081613, CAL0000081614]). THAILAND, Doi Sootep, 1615 m, 20.11.1910, A.F.G. Kerr 202 (K[K000597326]); Doi Sutep, 1676 m, 12.11.1911, A.F.G. Kerr 202 (K[K000597327]); Kao Kuap, Krat, 800 m, 26.12.1929, A.F.G. Kerr 0778 (K[K000597325]); Kao Pawta Luang Keo, Ranawng, 1300 m, 01.02.1929, A.F.G. Kerr 0703 (K[K000597324]); Panom Bencha, Krabi, 1300 m, 28.03.1930, A.F.G. Kerr 0815 (K[K000597328]).

Typifications: The name Monomeria crabro C.S.P.Parish \& Rchb.f. was published by Reichenbach in 1874 based on the collection of C.S.P. Parish from Moulmein, (now Mawlamyaing), Burma, and distinguished the species from $M$. barbata by the presence of lateral petals. The original materials could not be traced in any herbarium where Parish's specimens are reportedly located. Hence, the illustration associated with the description of Reichenbach is designated here as the lectotype according to Art. 9.12 of ICN (Turland et al., 2017).

Lindley (1830) described Monomeria barbata Lindl. based on specimens collected by Wallich from Nepal. Four relevant specimens (syntypes) were traced, three at K (K001114839, K000974243 and 
K000974273) and one at G (G00434759). None of these specimens was definitely designated as type by Lindley. Among them, K000974273 is designated here as the lectotype as it is a well preserved specimen with complete inflorescence.

\section{Discussion}

This study brings out two important points: 1) first legitimate record of the studied taxon, Bulbophyllum crabro, from Meghalaya, and 2) expands its taxonomic description based on observations of live materials. The lateral petals, not noticed and reported by Lindley $(1830,1836)$, are shown in the photographs for the first time, located strongly decurrent on the posterior side of the foot of the column, extending to distal end of foot until interposed between joints of lateral sepals on margins of foot. Four pairs of lamellae on the labellum or lip define the shape of the lip. Three pairs of lamellae are visible adaxially and one pair is visible only abaxially. Of these, two adaxial pairs appear converging towards the mid-lobe, all four lamellae on each lobe taper, merge gradually to form horn-shaped auricles. Lindley (1830) and King and Pantling (1898b) reported only two lamellae on each lobe, but this study illustrates four lamellae. The lip has the appearance of a bull's head and can be referred to as 'bull's head flower'. Seating of lip hinged on upcurved end of column foot by movable joint results into an interesting see-saw movement favourable for effecting pollination by insects.

\section{Acknowledgements}

The article is dedicated to Late Dr. S.K. Jain (former Director of Botanical Survey of India). The Department of Botany, North-Eastern Hill University, Shillong provided facilities during the doctor of science programme to the author. Dr. Chaya Deori, Scientist at BSI, Shillong, provided leads to the identification of this taxon as M. barbata. Howrah (CAL) granted permission to consult the herbarium. Dr. N. Odyuo (ASSAM) accepted voucher specimen (Coll. No. US005006). Mrs. Shilpi Agrawal and Amogha Shankar provided support during the study on growth of the orchid. The author expresses gratitude to the referees and chief-editor of Rheedea for innumerable suggestions and intensive verification of protologue.

\section{Literature Cited}

ABDULLAH E. 2007. The discovery of the genus Monomeria Lindl. (Orchidaceae) in Cameron Highlands: a new record for Malaysia. Folia Malaysiana 8: 41-49.

APG IV 2016. An update of the Angiosperm Phylogeny Group classification for the orders and families of flowering plants: APG IV. Botanical Journal of Linnaean Society 181: 1-20. https://doi.org/10.1111/boj.12385

AVERYANOV L.V. 1994. Identification guide to Vietnamese orchids (Orchidaceae Juss.). World and Family, S.Petersburg.

AVERYANOV L.V. 1998. Familiae Orchidaceae species novae et rarae in flora Vietnami. Novosti Sistematiki Vysshikh Rastenii 31: 39-67 (in Russian).

AVERYANOV L.V. \& A.L. AVERYANOVA 2003. Updated checklist of the orchids of Vietnam. Vietnam National University Publishing House, Hanoi.

AVERYANOV L.V. \& A.L. AVERYANOVA 2013. Updated checklist of the orchids of Vietnam. Vietnam National University Publishing House, Hanoi.

AVERYANOV L.V., HIEP N.T., LOC R.K. \& A.L. AVERYANOVA 2000. Preliminary orchid checklist of Cao Bang Province (Vietnam). Lindleyana 15: 130-164.

BENTHAM G. 1881. Notes on Orchideae. The Journal of the Linnean Society 18: 281-360. https://doi.org/10.1111/ j.1095-8339.1881.tb01258.x

CHEN X. \& J.J. VERMEULEN 2009. Monomeria Lindl. In: WU Z., RAVEN P.H. \& D. HONG (eds.), Flora of China. Volume 25: Orchidaceae. Missouri Botanical Garden Press, Missouri.

CHEN S., LIU Z., YIBO L., XIAOHUA J. \& T. ZHANHUO 2009. A field guide to the orchids of China. Huayu Nature Book Trade Co. Ltd.

GRANT C.B. 1895. The orchids of Burma. Hanthawaddy Press, Rangoon.

HAJRA P.K. \& D.M. VERMA 1996. Flora of Sikkim Volume 1. Monocotyledons. Botanical Survey of India.

HOOKER J.D. 1890. The flora of British India. Volume 5. L. Reeve \& Co., London.

JIN X.H. \& X.D. ZHAO 2009. Native orchids from Gaoligongshan mountains, China. Science Press, China. 
KERR A.F.G. 1911. I. Contributions to the flora of Siam. I. Sketch of the vegetation of Chiengmai. Bulletin of Miscellaneous Information, Royal Gardens, Kew 1911: $1-60$.

KING G. \& R. PANTLING 1898a. The orchids of the Sikkim Himalaya, Part 1. Letterpress and Part 2. Plates of Malaxideae. Annals of the Royal Botanic Garden (Calcutta) 8 (1-2): 1-342, pls. 1-133.

KING G. \& R. PANTLING 1898b. The orchids of the Sikkim Himalaya. Part 3. Plates of Epidendrae and Vandeae, and Part 4. Plates of Listereae, Goodyereae, Ophrydeae and Cypripedieae. Annals of the Royal Botanic Garden (Calcutta) 8(3-4): pls 134-448.

KRESS W.J., DEFILIPPS R.A., FARR E. \& D.Y.Y. KYI 2003. A checklist of the trees, shrubs, herbs, and climbers of Myanmar (revised from the original works by J.H. Lace, R. Rodger, H.G. Hundley \& U Chit KoKo on the 'List of trees, shrubs, herbs and principal climbers, etc. recorded from Burma'). Contributions from the United States National Herbarium 45: 1-590.

LINDLEY J. 1830. The genera and species of orchidaceous plants. Ridgways, Piccadilly, London.

LINDLEY J. 1836. A natural system of botany; or, a systematic view of the organization, natural affinities, and geographical distribution of the whole vegetable kingdom. Longman, London.

LUCKSOM S.Z. 2007. The orchids of Sikkim and north east Himalaya. S.Z. Lucksom.

MAO A.A., SINHA B.K., VERMA D. \& N. SARMA 2016. Checklist of flora of Meghalaya. Botanical Survey of India, Kolkata.

ORMEROD P. 2011. Orchidaceous additions to the flora of China. Taiwania 56: 42-49.

PEARCE N. \& P. CRIBB 2002. The orchids of Bhutan (flora of Bhutan: including a record of plants from Sikkim and Darjeeling). Volume 3(3). Royal Botanic Garden, Edinburgh.

POWO 2020. Plants of the World Online. Kew Science, UK. Available at: http://powo.science.kew.org. (Accessed on 30.05.2021).

PRIDGEON A.M., CRIBB P.J., CHASE M.W. \& F.N. RASMUSSEN 2014. Genera Orchidacearum. Volume 6. Epidendroideae (Part 3). Oxford University Press, Oxford.
REICHENBACH H.G. 1874. Enumeration of the orchids collected by Rev. C.S.P. Parish in the neighbourhood of Moulmein, with descriptions of the new species. Transactions of the Linnean Society of London 30: 133-155.

ROLFE R.A.R. 1910. Monomeria barbata. The Orchid Review 18: 30-31.

SEIDENFADEN G. 1986. Orchid genera in Thailand XIII: Thirty-three epidendroid genera. Opera Botanica 89: 1-216.

SHANKAR U. 2021. Enumeration of the flora of Northeast India - Onelist of over 10,000 taxa of flowering plants. AFB Flora Series on Flowering Plants of the Indian Subcontinent. Volume 1. First Edition. Arshuma Famous Books, Agra.

SINGH S.K., AGRAWALA D.K., JALAL J.S., DASH S.S., MAO A.A. \& P. SINGH 2019. Orchids of India - a pictorial guide. Botanical Survey of India, Kolkata.

TRIPATHI A.K. \& U. SHANKAR 2014. Patterns of species dominance, diversity and dispersion in 'Khasi hill sal' forest ecosystem in northeast India. Forest Ecosystems 1: 1-20. https://doi.org/10.1186/s40663-014-0023-2

THOUARS L.A. DU PETIT 1822. Histoire particulière des plantes orchidées recueillies sur les trois îles Australes d'Afrique, de France, de Bourbon et de Madagascar. L'auteur, Paris.

TURLAND N.J., WIERSEMA J.H., BARRIE F.R., GREUTER W., HAWKSWORTH D.L., HERENDEEN P.S., KNAPP S., KUSBER W.-H., LI D.-Z., MARHOLD K., MAY T.W., MCNEILL J., MONRO A.M., PRADO J., PRICE M.J. \& G.F. SMITH (eds.) 2017. International code of nomenclature for algae, fungi, and plants (Shenzhen Code) adopted by the nineteenth International Botanical Congress Shenzhen, China, July 2017, Regnum Vegetabile 159. Koeltz Botanical Books, Glashütten. https://doi.org/10.12705/ Code.2018

VERMEULEN J.J., SCHUITEMAN A. \& E.F. DE VOGEL 2014. Nomenclatural changes in Bulbophyllum (Orchidaceae; Epidendroideae. Phytotaxa 166: 101-113. https://doi.org/10.11646/phytotaxa.166.2.1

XU Z., JIANG H., DEPING Y. \& E. LIU 2010. The wild orchids in Yunnan. Huayu Nature Book Trade Co. Ltd. 